\title{
Between Home and Exile A Reading of the Exilic Experience of the Iraqi Poet Adnan Al-Sayegh
}

\author{
Hana Khlaif Ghena \\ College of Arts, Department of Translation, Al-Mustansiriyah University, Iraq \\ E-mail: h.horizons2013@gmail.com
}

Doi:10.7575/aiac.alls.v.7n.3p.100

Received: 18/01/2016

URL: http://dx.doi.org/10.7575/aiac.alls.v.7n.3p.100

Accepted: 08/03/2016

\begin{abstract}
This paper aims at exploring the exilic experience of the Iraqi poet, Adnan Al-Sayegh whose involuntarily departure from his homeland, Iraq, in the early 1990s made him suffer a strong sense of estrangement, nostalgia, selffragmentation and disconnection. The paper is divided into three sections and a conclusion. Section one sheds light on the circumstances that forced Al-Sayegh into self-exile. Investigating these circumstances necessarily entails a discussion of the concept of exile, its nature and consequences, which is the subject of section two. Section three examines a number of poems that typically translates Al-Sayegh's deep sense of dislocation and disaffection in his new host lands. The conclusion argues that exile as a physical, geographical, and psychological state of being is a 'basic condition,' in Al-Sayegh's poetry and life.
\end{abstract}

Keywords: Exile, Iraq, Al-Sayegh, estrangement, and nostalgia

Exile in Adnan Al-Sayegh's Poetry

Iocasta: What means exile from one's country? Is it a great evil?

Polyneices: The greatest; harder to bear than tell.

(Euripides's The Phoenician Women)

\section{Iraxile or living in Exiles within Exiles}

Looking for a word or a term that best illustrates the synonymousity of Iraq as a country that is continuously pushing his people to opt for self- or forced exile and exile as geographical, cultural, and psychological displacement, I think of coining the word 'iraxile' which, in my opinion, best illustrates what Iraqis have been undergoing in the second half of the twentieth century up to the present time. During this long period, the Iraqis were writhing under various forms of pressures and stifling circumstances ranging from tyrannical authority, a series of political upheavals, prolonged and successive wars, and economic sanctions to absence of freedom of speech and living in a continuous state of fear and misery. Sadly enough, the Iraqis in those times, Al-Athari (2008,p.vii)points out, "could only watch as their country was, and still is, being torn apart by the havoc of war, insurgency, and sectarian violence" which erupted in the wake of the second Gulf war and post-2003 Iraq. The Iraqis, as a matter of fact, were living in those times in the "Republic of Fear," as the Iraqi exile Kan'an Makiya describes it (See Makiya 1989).

In an interview with Makiya, Johnson (December 16,2005,p.1) states that Makiya's Republic of Fear: Inside Saddam's $\operatorname{Iraq}(1989)$ is now widely acknowledged as a classic text on the nature of the totalitarian system that reigned supreme for about thirty five years in Iraq, from the Arab Ba'ath Socialist Party assumption of power in 1968 to the overthrowing of Saddam in 2003. The importance of the book, according to Johnson, is three-fold. First it exposes the true nature of the totalitarian violence and unveils its true role in Saddam's Iraq; second, it traces the genealogy of that totalitarianism across the generations, and its seepage into intellectual, social, political and military milieus; and third, it sheds light on the pernicious impact of that appalling political and intellectual culture at a psychic as well as institutional level, "an impact that weighs down on the effort to build a new Iraq today," Johnson shrewdly notes(Ibid, p.5).

In the same interview, Makiya acknowledges his indebtedness to Hannah Arendt's groundbreaking Origins of Totalitarianism(1951). Through reading Arendt, Makiya was able to "understand power and political authority in a wholly new way." In her analyses of the nature of the front organizations, how they work, how power was exercised through them and her wide-ranging study of how states operate through networks of informers to exercise power, Arendt provides Makiya with a "model of how to understand... the Ba'ath front organizations" (Johnson, p.6). 
Makiya concurs with Arendt that "totalitarianism is the most radical denial of freedom" (1951, p.1). Similar to Arendt whose main concern was to describe the mechanics of the totalitarian political movements such as Nazism in Germany and Communism in Russia, Makiya "regards Ba "thist Iraq as a hybrid between Stalinism and Nazism [and]... likens the Ba “th's pan-Arabist ideology to European fascism, particularly German National Social Party" (Rohde,2010, p.3).

In his analysis of the unique characteristics of the totalitarian societies, Friedrich (1953,pp.52-3) notes that there are a number of aspects which can be grouped around five closely linked clusters of characteristic features. They are first, an official ideology that covers all vital aspects of man's existence; second, a single mass party consisting of a small percentage of the population; third, a technologically conditioned near-complete monopoly of control of all means of effective armed combat; fourth, a similarly technologically conditioned near-complete monopoly of control of all means of effective mass communication; and fifth, a system of terroristic police control, depending for its effectiveness on the third and fourth points.

Immediately after its seizure of power in a notorious coup d'état in July 1968 after a "long history of political instability and repression" (Lewis, qtd in Al-Athari,2008, p.2) in which politics in Iraq was "bathed in bullets and blood...[and] had evolved into a Darwinian struggle to survive,"( Anderson and Stanfield, 2004,p.49), the Arab Ba'ath Socialist Party embarked on a massive campaign to subjugate and "reshape Iraqi society in the image of Saddam Hussein and his regime" (Dodge, 2003,p.57). In order to achieve this goal, the party adapted the above-mentioned five aspects and elaborated on them. It extensively depended on propaganda, indoctrination, sectarian discrimination, surveillance, terror practiced through its security agencies, and rewriting of history to "discipline the population and to destroy autonomous social structures" and to ensure the survival of the regime (Rohde, 2010, p.11). This comes in accordance with what Nalepka and Sassoon state about the oppressive nature of the Ba'ath's rule of Iraq. In her seminal study "Saddam is Iraq and Iraq is Saddam: Saddam Hussain's Cult of Personality and the Perception of his Life and Legacy", Nalepka blatantly states

There was a single party at the center of power in [Iraq], with its tentacles extending into every aspect of society and politics and into the lives of its members, backed up by incessant spying, and never hesitating to kill, imprison or torture anyone suspected of disloyalty. (2014, p.13)

In fact, the tendency of the Ba'ath Party to dominate all aspects of life is made crystal clear in the following official declaration:

We [the Party] have to emphasize that this society is led by a party, and that party is the Arab Ba th Socialist Party... which leads [the people] in its values, its organizations, and also leads it in its ideas and its policies.... Thus it is necessary that the party's values and ideologies are at the forefront of these activities, and throughout the country's decision-making apparatus. (qtd in Sassoon, 2011,p.34)

More dangerous and alarming is the rise of what is widely-known in the modern Iraq studies as 'Saddamism'reminiscent of Stalinism and Maoism- which typically means the reduction not only of the Party, but also of Iraq itself to the figure of its 'One and Only' or the 'necessity' leader, Saddam Hussain. In fact, after his taking over of the presidency in 1979 until his overthrowing in 20003, the Party, Sassoon (2011, p.39) remarks "devoted an enormous amount of energy and resources to building up the image of its leader, and from the mid-1980s the Ba th's philosophy and political education came to embody a cult rather than a political ideology." This implies a gradual and menacing movement from the one party rule to the one man rule (Anderson and Stanfield,2004, p.58) and ushers into the emergence of what is called a "Shadow State" in which Saddam, the "dictator and his narrow inner circle" became the sole political, economic and social movers' in the Ba 'thist Iraq (Rohde, 2010,p.3). In this State, "Autonomous collective social structures beyond the control of the state simply do not exist."(Ibid) As such, it is not strange to hear people talk of Iraq as "Saddam's Iraq." Iraq as a country was sacrificed on the altar of Saddam's despotism and thirst for absolute power.

This gives rise to what is called Saddam's 'Cult Personality,' or self-promotion. Nalepka defines the cult of personality as the "use of mass media, propaganda or other methods to create an idealized, heroic, and at times, worshipful image, often through unquestioning flattery and praise" $(2014$, p.6). The systemic idolization of Saddam was expressed through every medium, projecting him as a superhuman capable of doing all things perfectly. His cult of personality immediately invaded Iraqi society, as thousands of portraits, posters, statues and murals were erected in his honor all over Iraq. His face could be seen on the sides of office buildings, schools, airports and shops, as well as on all denominations of Iraqi currency (Sassoon, 2011, 174).

Saddam's monopoly of the authority, his single-handedness, reckless and repressive policies, and his ceaseless efforts at self-aggrandizing result in embroiling Iraq into two successive wars: Iran-Iraq war (1980-1988) commonly known as the First Gulf War and The Second Gulf War (1990-1991) after the Iraqi invasion of Kuwait, followed by twelve year sanctions that depleted the economic and human resources and render Iraq more divided and worn out than ever. No doubt, these wars and unsettling circumstances caused incalculable damage-human, material, social, and environmental - to Iraq whose people fell victims to various forms of displacements, ordeals, and shocks. As a result, thousands of Iraqis chose exile rather than living under a regime that continuously stifles their aspirations and kills their dreams. Just like Scotland under the reign of Macbeth, Iraq can no longer be called a 'MOTHER', rather, it becomes a 'MASS GRAVE' for its people. 
Unfortunately, after the collapse of the Ba'ath regime in 2003, and contrary to the Iraqis' expectations of a new era of freedom, democracy, and prosperity, Iraq plunges into another flurry of violence, war, and traumas. In "As Iraqis See It," Messing succinctly described the situation of Iraqis 'expressing anger and gloom, exasperation and despair.' He says:

The overwhelming sense is that of a society undergoing a catastrophic breakdown from the never-ending waves of violence, criminality, and brutality inflicted on it by insurgents, militias, jihadis, terrorists, soldiers, policemen, bodyguards, mercenaries, armed gangs, warlords, kidnappers and everyday thugs. 'Inside Iraq' [the name of the Iraqi blog he is describing] suggests how the relentless and cumulative effects of these various vicious crimes have degraded virtually every aspect of the nation's social, economic, professional, and personal life. (qtd in Adelman, 2008, p.184)

Massing went on to describe "the huge exodus out of Iraq," that has "deprived the country of many of its most competent citizens."(Ibid) whether voluntary or involuntary, exile was the only option left for many Iraqis to continue living.

\section{Exile: A Conceptual Background}

Although 'Exile,' as a geographical, cultural, and psychological displacement, is not a new phenomenon in the history of mankind, there is a general agreement among thinkers and critics that it constitutes a major characteristic of modern age. In his critically seminal book Culture and Imperialism, Said (1994,p.332) describes the production of "more refugees, migrants, displaced persons, and exiles" as "one of the unhappiest characteristics" of the twentieth century. In fact, those figures become, Dobrinescu (p.101) asserts, "emblematic of the contemporary world". The fact that "Many writers and artists of the [modernist] period worked in someone else's metropolis" (Carr qtd in Camelia,p.75) attests to this observation. This results in the emergence of a "literary canon of exile"(Ibid) to which such modernist writers as James Joyce, Gertrude Stein, T. S. Eliot, Ezra Pound and D. H. Lawrence contribute. As a result, "[E]xile is no longer perceived as a banishment or expulsion from one's homeland but rather a condition commonly shared by a network of writers" (Shaw qtd in Tsaaior, 2011, p.98). The term 'exile,' here refers not only to a person who has been detached from his/her homeland, but also to the act of being detached (Hanks, 1974, p.561).

No doubt, this long history of 'exile' witnesses drastic changes in the people's perceptions of and attitudes towards it. However, whether it is individual/collective, internal/external, or voluntarily/involuntarily, exile retains, in all cases, its essential characteristics since it means:

not only years of aimless wandering away from family and familiar places but also being a permanent outcast, someone who never felt at home and was always at odds with the environment, inconsolable about the past, bitter about the present and future. (Said 1996,p.47)

More significant and alarming is the "association between the idea of exile and the terrors of being a leper, a social and moral untouchable" (Ibid).

Said $(2000,181)$ defines 'exile' as "the unhealable rift forced between a human being and a native place, between the self and its true home: its essential sadness can never be surmounted." This definition implies a deep sense of loss and separation from one's own culture, language, familiar places, local community, and from the self. (Lagos-Pope, qtd in Buzarna-Tihenea, p.83) In other words, exile is a "solitude experienced outside the group: the deprivations felt at not being with others in the communal habitation" (Said, 1990, p.359).

The factors that contribute to making an individual or a community leaves its original home vary. They range from famines, wars, economic crises, ethnic cleansing, diseases, religious conflicts, political and social oppression to globalization which results in the movement of "vast numbers of people in large-scale migrations between regions, countries and even continents, making them face the sense of being uprooted and the concomitant need to remould their identity under the new conditions"(Kurdi 2010,p.58).

The variety of factors that compel a person to leave his homeland link 'exile' as a term to a large semantic domain including words like 'immigrant, expatriate, refugee, guest worker, exile community,[and] ethnic community"'(Tololyan qtd in Ropero, 2003, p.7). In the same vein, Tabori (1972, p.23) notes certain synonyms and connotations for the term 'exile,' such as “displace, send out, ..., dislodgement, eviction, ejectment, deportation, ... relegation, extradition, [and] excommunication." As such, the exile can be defined as

a person compelled to leave or remain outside of his country of origin on account of wellfounded fear of persecution for reasons of race, religion, nationality, or political opinion; a person who considers his exile temporary...hoping to return to his fatherland when circumstance permit-but unable or unwilling to do so as long as the factors that made him an exile persist. (Ibid)

In The Geography of Modern Drama, Chaudhuri argues that dislocation, separation and geographical homelessness often evoke "a new geopathology", according to which "the exhausted poetics of exile and the defunct heroism of 
departure are replaced, $\ldots$ by the anxiety of immigration $[\ldots]$ figured as a search for a new and compelling narrative of self-definition" (qtd in Kurdi, 2010, p.59).

Just as the nature and reasons behind exile vary, the attitudes towards its ultimate outcome vary too. In fact these attitudes can best be described as ambivalent. It is either viewed as something that "produces creative freedom or something that traps the protagonist in restrictive nostalgia; it either enables the exiled to function freely of the limitations of the local, or it is profoundly nostalgic and yearns for the lost"(Iamandi, p.173). Said(2000, p.181) concurs to this view for although he does not deny the 'transformative,' 'heroic,' and 'even triumphant episodes in an exile's life," these are, he explains are "no more than efforts meant to overcome the crippling sorrow of estrangement. The achievements of exile are permanently undermined by the loss of something left behind forever."

Said's stress on the corollary sense of loss and alienation embedded in the act of displacement alludes to the traumatic nature of the exiling experience. However, Kurdi(2010, pp.58) remarks that the crossing of geographical and cultural borders, is not necessarily just traumatic without psychological gain or spiritual growth. She quotes Chambers saying that the experience of exile is likely to generate "a form of restless interrogation" since:

to come from elsewhere, from 'there' and not 'here', and hence to be simultaneously 'inside' and 'outside' the situation at hand, is to live at the intersections of histories and memories, experiencing both their preliminary dispersal and their subsequent translation into new, more extensive, arrangements along emerging routes. (In Ibid pp.58-59)

This results in the emergence of a multi-dimensional discourse of exile that presents it as a means of resistance to any kind of oppression, and at the same time as a means of reintegration, of 'rebirth', of a repositioning of the self within the world (Mitrea, p.127). The discourse of exile, Mitrea adds, is also a "discourse of remembering, of recreating old paths, creating places of safety in one's mind, sheltering escape realms, so that the terrors of the past will not surface again"(Ibid). These discourses of exile are deftly demonstrated and translated into poignant images in the poetry of AlSayegh who spends most of his life in exile and, as a result, is torn apart between his emotional attachment to his homeland and his feeling of disconnection due to his physical displacement in his exile(s).

\section{Adnan Al-Sayegh: The Poet Who Carries Exile under his Armpit}

In his detailed biography which dribbles with the images of suffering, alienation, and despondency, Al-Sayegh (1955-) vividly talks about the circumstances that forced him to leave his homeland and live in exile since the early 1990s. However, the exile as presented in Al-Sayegh's poetry is not confined to the involuntary physical displacement from one's own homeland and community. In fact, Al-Sayegh suffers both types of exile: the internal and the external. Long before his physical flight from Iraq to countries, climates, cultures, and languages alien to him, Al-Sayegh has been living in an internal exile. This means that he was in exile while rooted in his homeland without being physically displaced. This is, Tsaaior $(2011$, p.100) argues is the "spiritual exile which registers itself in terms of absence through presence." These two types of exile are occasioned by a series of traumatic experiences that range from his participation in the prolonged Iran-Iraq war, political oppression, inner insecurity, absence of freedom of speech and literary and cultural censorship which threatens the poet's essential being and poetic outputs.

Al-Sayegh begins his biography by saying "In this dubious evening, the evening of exile and homeland "(2004, p.690). In equating exile with his homeland, Al-Sayegh bluntly alludes to the infernal living conditions which compel not only him, but also thousands of Iraqis to opt for leaving Iraq in successive waves of exoduses.

AL-Sayegh's obsession with talking about the brutalities of war sheds light on the decisive role it plays in his personal and poetic development. Like other Iraqi poets whose poetic creativity burgeoned in the 1980s, i.e., during the Iran-Iraq war, Al-Sayegh belongs to what is critically known as 'The Eighties Generation,' 'The War Generation,' and 'The Shadow Generation'(Al-Saqar, qtd in Al-Ubaidi, 2002). It is a generation that spent most of his early life and youth in the catastrophic kiln of war; a generation that had been living in the midst of "destruction, death, blood shedding, oppression, sanctions, and alienation. We were either exiles in our own homeland or martyrs on the waiting list" (AlSayegh, 2004, p.709).

Al-Sayegh reminiscences of his youth which was dissipated in the battlefields and the military sites over which the "rockets and bombs were dancing on the war's mad rhythms" (Ibid, p.691). He calls to mind the painful experience of being imprisoned in an abandoned animal stable for about two years (1984-1986) because the officer caught him redhanded with a number of books the authorities considered banned. He harks back to the tragic death of "that poor mule by a landmine after which it was turned into a fountain of blood; splintered pieces of flesh and heavy rising dust" (Ibid, p.693). He agonizingly remembers many of his friends who either "withdrew from life, assassinated, made homeless, or fell down." Al-Sayegh succinctly describes the situation of the Iraqi soldiers in the Iraq-Iran often 'forgotten war': "We, the soldiers, were alone there.... in front of us are the death and bullets, beneath us are the remains of our comrades-inarms, behind us were the death squads, and above us is a sky of smoke, shrapnel....we were soundlessly dying, rotting, and buried" (Ibid, 694).

As a poet, Al-Sayegh's first confrontation with the repressive authorities took place in the mid-1975 when he was fired from the Institution of Agriculture because of a poem he recited and was considered anti-government. The confrontations continued until they culminated in his being blacklisted by the despotic Uday, the notorious son of the then head of the State, Saddam Hussain after the staging of He who Stayed Wakeful in his Hallucination (1993), a play 
adapted by the Iraqi director, Ihsan Al-Talal from Al-Sayegh's poem "Hallucinations inside a Skull which has Nothing to do with Adnan Al-Sayegh." Al-Sayegh was forced to flee to Amman, Jordan and "say goodbye to the land of famines and oil" in the same year after being sentenced to death and informed that Iraq was no longer a safe place for him and his family(For more information see Al-Sayegh, 2004, pp.702-707).

In a manner reminiscent of T. S. Eliot, Al-Sayegh presents Iraq from which he is physically displaced as "A heap of broken images." It is a big dungeon or a Dante-like Inferno in which life becomes excruciating. In "I Survived the War by Mistake," he says:

I went out of time of betrayals,

Towards a noble cry over a green 'homeland,'

Tilled by pigs and worms.

I entered the orbit of the poem,

Half-free, half-handcuffed.

Behind me the bark of the futile wars

Which the General sent out to snap at our flesh.

I ran, ran, ran in the forest of death

.......between bombs and martyrs.(2004, p.296, the poems are my translation)

It is this internal exile from which Al-Sayegh strove to find a way out that establishes his exilic experience within the autobiographical mode. In fact, Alsayegh's incessant reference to the frustrated alienated, and psychologically displaced ' $\mathrm{I}$ ' throughout his poetry is indicative of the traumas he has been through in Iraq. Though spiritually excruciating, leaving Iraq was the only solution Al-Sayegh finds to alleviate the sense of inner collapse. However, in spite of the freedom he enjoys in his exile in writing poetry and living his life, he is not completely free: he is "half-free/half handcuffed," in clear reference to the state of ambivalence most exiles experience in their exiles.

In section three of his poem "Papers from the Autobiography of that who carried his Exile under his Armpit,"(henceforth Papers) he emphatically declares:

I am going to pack my bags,

And my tears,

And my poems,

And leave this land.

Let us carry our graves and children.

Let us carry our sighs and dreams, let us go

Before they steal them,

And resell them to us in our homeland:

Fields of banners;

And in our exiles, a homeland in installments.(2004, pp.93-4)

Al-Sayegh's decision to leave was not voluntary. Rather it was taken after a long time of deliberation and waiting for things to get better. Regrettably, his contemplation of what was going on in Iraq led him to one conclusion:

This land is no longer good for anything.

Oh! This land

The more it overflows with blood and oil,

The more it overflows with opportunists and hypocrites.(Ibid, p.94)

The reference to the 'opportunists' and 'hypocrites' in the last line is a clear indictment of all parasite-like and selfinterested people who deplete the energy of Iraq and ravage its soul. However, in spite of all these ordeals and dissatisfactions, Al-Sayegh cannot help but love and nostalgically talks of his homeland and feel sorry for it. In the last lines of this section, he wonders:

What kind of homeland is this? 
In spite of this,

As soon as we walk a few steps away from it,

We break down out of nostalgia and homesickness

On the first sidewalk of exile we come across.

So we rush to the box offices to embrace them and cry.(Ibid, p.95)

After forty years of living under the "scorching sun of Iraq, the sand, the wars, the oppression, and agony"(Al-Saygeh, 2004, p.723), Al-Sayegh found himself in a completely new environment which forced him to make a series of adjustments and adaptations. He was quite apprehensive of his being ever able to cope with the requirements of dealing "with the frost which surrounds [him] in this snowy and remote city that sleeps in the lap of the North Arctic" (Ibid).

The change in the climate was not the only challenge which Al-Sayegh had to deal with. Certainly, he, as an exile, has faced other challenges on the linguistic, cultural, and psychological levels. What was more important to Al-Sayegh, as a poet, was the freedom of expression he began to enjoy in his exile. In his new host country, Al-Sayegh (2004) was enthralled by the fact that "the freedom of the individual in writing, life, behavior, and expression has the greatest value and is of prime importance"(p.724). He realized that in moving from Iraq to the Swedish Lolio, the first city of exile outside the Arab countries, he "was moving from the highest degree of repression and tyranny to the highest degree of freedom and liberty"(Ibid).

Since the 'exile text' is in essence a 'memory text,' Al-Sayegh, similar to other exiles, faced the dilemma of coping with and overcoming the horrendous memories of his war-torn homeland that kept haunting him. In an attempt to explain the role of memory in the shaping of his exilic experience, Al-Sayegh says

As soon as I take my pen to write about the forests of the snow-covered and huge Yolkran trees [in Lolio], for example, the nightmares of wars, prison cells, torture, and suffocation relentlessly attack and haunt me to rob the lines of the poem of everything that is beautiful and sparkling. (2004, p.724)

Al-Sayegh, as a result, keeps distressingly wondering "What can I do with is sponged memory that is bursting of blood, sand, and ashes? How long I am going to live in this ambivalent state of being? And if I am to choose, which 'homeland' I am going to have? The lost, my country of origin or the new country of exile?'(p.723-724).

This state of restlessness, of "inbetweenness", of trying to find what he has lost in the new geographical locations, throws Al-Sayegh into a state of ceaseless physical movement among cities, countries and 'virtual' homelands. In his Complete Poetical Works and the collection of poems entitled And (2011), the names of no less than thirty cities and locations are mentioned, among them are the British Bristol, the Swedish Malmo, Cairo, London, Berlin, Paris, Toronto, New Zealand, Copenhagen, Stockholm, Chicago, Gutenberg, Dubai, Abu Dhabi, Damascus, Masqat, Prague, Cuba, Amman, , Doha, Morocco, Bari in Italy, Beirut, etc. In all these places, whether he is in a café, a university, a conference, a bar, on a beach, in a metro, a bus station, over a bridge, or in a library, Al-Sayegh keeps talking about the predicaments and afflictions of Iraq and its people. He is carrying his lost homeland in his heart, under his armpit, inside his bags, between his lines.

In the poems named after the places of exiles like 'Paris," "The Night of Lisbon", "Rain in London," “ A Swedish Relationship," "Diasporas," "The Sparrows...Die in Beirut," and "Lolio", Iraq, with its rivers, mountains, bridges, cities, people, history, and ordeals, is always there. As soon as the poet begins talking about or describing a scene in these cities, he immediately switches back to Iraq to present tear-jerking images of deprivation and dispossession that stand in stark contrast to the images of abundance and joy he has in them.

In "Paris," which takes place in a Parisian bar, images of dancing, drinking, of Eiffel Tower, of Arthur Rimbaud, of Jean Paul Sartre, of beautiful girls are meaningfully and suggestively juxtaposed with images of death-struck and warravaged Iraq. The poet realizes that what has happened to his homeland is beyond description. Therefore, he wonders

From where to begin?

My glass of wine is overfilled with sorrow and desolation

While Paris is overfilled with madness and love.

Lonely my heart cries: Iraq.....Iraq.....Iraaaaa...Irrrrrrrr....IIIII.(2011, p.39)

Al-Sayegh keeps crying 'Iraq' until his voice dies down without getting an answer. The scene in the Parisian bar is repeated in another bar in Lisbon. In spite of his being surrounded by irresistible temptations like melodious rhythms, bleu-eyed and lusty-lipped girls, dancing and glasses of wine, there is only one thing he keeps thinking of: Baghdad, the city of his youth and old pals. In "Diaspora", he addresses the diaspora telling it: "Oh! Diaspora which becomes a homeland for me/ I am going to furnish my exile.”(2011, p.175) But the pieces of furniture he chooses are made of his memories of the river Euphrates, his lost years in Iraq, his old books and table, and his mother and old friends. Again the poem contains references to the bars of London, Beirut, Malmo in which the poet spends a lot of his time in an attempt to forget. Nothing remains of his homeland except those ghost-like memories that keep haunting him. In 
relation to this, Al-Sayegh staunchly holds the view that "the physical displacement from one's homeland as a place of living does not mean forgetting his afflictions and dilemmas."(Al-Zareebi,2008, p.13) When Al-Zareebi comments that the Al-Sayegh's choice of self-exile is not strange or exceptional since it was the fate of many Iraqi poets, intellectual and thinkers to live and die in exile, Al-Sayegh agrees and mentions the great Muhammed Mahdi Al-Jawhiri, AbdulWahab Al-Bayati, Buland Al-Haidri, Mustapha Jamil-Aldin, Kamal Sabti as examples of poets who chose exile as an "outlet and a safe haven from the oppression, nightmares and the political and social pressures which fence them in in their homeland"(Ibid, p.21). To this, Al-Sayegh adds that unlike the migratory birds that usually return to their nests, many of the Iraqi poets were destined to live and die in exiles. Al-Sayegh himself is hopeless of ever returning to Iraq. After the overthrowing of Saddam, he thinks of making a stop and returning. In "Nostalgia," in the collection of poems Papers (2004), Al-Sayegh presents a series of images of loss, damage and hopelessness. He says:

In the shadow of date palms,

I have a gun-immured homeland.

How to access it,

The distance between us had become longer,

And the admonition sharper.

How can I access my old pals?

Those who were sent away in jail-cells,

Or became potbellied,

Or inhumed.

It is an ordeal to see -after twenty years-

A different bridge from that you once crossed

A different sky,

And people who are haunted by absence.(2004, p.14)

Whether he is outside or outside Iraq, Al-Sayegh is alienated and estranged. The juxtaposition of date-palms, symbol of pride and fertility with the wall of guns, symbol of death and destruction sheds light on the unnatural circumstances Iraq, "As a Homeland of Wars," to borrow Al-Sayegh's words, had been through. In 2004, Al-Sayegh thinks of putting a stop to exile and returning to Iraq. However, what he finds in post-Saddam Iraq was a homeland more divided and troubled than ever with the new challenges of explosions, internal war-induced displacement, violence, religious and sectarian extremism, and corruption. In another poem named after 'Iraq', Al-Sayegh personifies 'Iraq' presenting it as a man who is on the run from one place to another as a result of his being continuously hounded by muzzles of guns, fear, and despots. This man is living in a continuous state of exile with no hope of ever settling down or finding a real home:

'Iraq' who stays away,

Whenever his footsteps become wider in exiles

And 'Iraq' who moves slowly,

Whenever a window is half-opened

I said: "Ahhhhhhhhhh"

And 'Iraq' who trembles,

Whenever a shadow passes by,

I imagine a muzzle of a gun lying in wait for me

Or exiles.

And the 'Iraq' we miss

Half of its history is songs and kohl (eyeliner),

And half of it is despots. (2004, p.15)

In spite of the freedom he enjoys in the host countries he keeps travelling to, Al-Sayegh feels strange and out-of-place. The nightmarish memories of his dead, exiled and lost friends, members of family, and life-companions keep haunting and whipping him. He cannot feel happy and enjoy his life while his homeland is still suffering. Therefore, he keeps looking nostalgically back to a homeland damaged by wars. It is this nostalgia that makes him live in a continuous state of ambivalence, belonging to no place and divided by culture, geography, history and climate. In a telling comparison between his original homeland and his host country in a three-part poem called "New Year Texts," Al-Sayegh juxtaposes a cultural and religious practice typical of western countries, i.e., the celebration of the New Year or Christmas, with a series of suffocating images he recalls from Iraq. 
In the first part, Al-Sayegh vividly describes his feelings of loneliness and despondency in the New Year: "The snow falls down/ on my heart/ in the streets of the New Year/And I am alone/Walled by those who disappeared of died"(2004, p.73).

In the second part, this feeling of loneliness and estrangement becomes sharper and more heart-rending as the poet resembles himself to an imprisoned sparrow that is eager to fly freely. He says "Each [New] year/people clasp in the arms/Press to the bosoms/while I intently stare/Through the window of exile/ To my homeland/ Like a sparrow that sends his astray look/from behind the bars of his cage/To the Spring." Of course, the metaphorical connotation implied in the use of 'sparrow' and 'spring' is crystal clear. The 'sparrow' that stands for the poet, and by implication, for Iraqi people, wants to get out of his inferno-like abode (Iraq) to enjoy the wider horizons of freedom and creativity, or 'spring.' In this sense, the homeland which Al-Sayegh keeps remembering is recreated in what might be safely called his 'exile poems.'

This sense of poignancy and tragic loss culminates in the third part which tells of a strange visit paid by Papa Noel (Santa Claus) to the poet's homeland. However, instead of the atmosphere of joy and pleasure that usually accompanies such a visit; an atmosphere of disappointment, disillusionment, and frustration take the characters of the poem in its grip. What Papa Noel finds is a homeland that becomes an abandoned house unsuitable for living. Al-Sayegh vibrantly articulates:

Each [New] Year,

Papa Noel stands at the door of [my] Homeland.

He knocks and knocks and knocks.

No one there to answer him:

The fathers went early to the battlefields,

The mothers grew old in the empty pots,

The Generals went to the radio station,

To deliver speeches and felicitations,

While the children became disheartened,

So they slept near the trash bins

To dream of presents,

Appropriate for their postponed childhoods.(2004, pp.73-4)

Al-Sayegh in Section 12 of "Papers" declares his acceptance of his state of being as an exile. He tries to create a new homeland made merely of the words of his poems. His poems become his 'virtual' homeland. Here, writing poems has a therapeutic function as it helps Al-Sayegh to psychologically cope with the traumas of being separated from his homeland. In this sense, he echoes the African writer Chinua Achebe who defines his writings as part of a "process of re-storying peoples who had been knocked silent by the trauma of all kinds of dispossession"( Rodrigues, 2007, p.1) He says:

I am a travelling poet.

My hands are in my pockets,

And the sidewalks are my pillow.

The poem is my homeland. $(2004$, p.101)

In his new homeland, the poet is living alone. He is not having a real life of his own. He is panic-stricken and feels cold. As such, the pervasiveness of the images of loneliness, coldness, and isolation in this section is not surprising. He evocatively translates these images in the following lines:

Alone, I gulp the boredom and the dregs of the forgotten drinking glasses on the tables,

Alone, I rub myself against the young girls' plump buttocks in the bus stations.

Only the empty seats are there for me

Only the ships for which no one waits are there for me

No bread, no homeland and no mood are there for me. (Ibid, p.101)

Nothing can compensate the homeland in the poet's heart. When Al-Sayegh left, he thought that his would be a temporary exile. However, as the years drag on and circumstances become worse, the poet's feelings of alienation and homesickness grow sharper and deeper. Therefore, he speaks out in Section 14 of "Papers":

I'm gonna sit at the door of my homeland hunchbacked,

Like a sad song emitted from an empty field, 
The snow and the dried leaves of tree cover me.

I look to the swarms of the returnees from their exiles

Like the fatigued birds.

I wipe the snow and alienation from their eyelids.

They are coming back,

But who gives them back what they have lost

Of sand and dreams and years. (Ibid, p.103)

He harks back to his dreams of returning in the very moment he opted for exile. But he later realizes that his is a permanent exile. He says:

I took-off in the first train to exile

While I was thinking of coming back.

The railway becomes old,

And its wheels become frayed.

And my clothes become threadbare out of washing.

And I am still a traveler in the wind,

Unceasingly flying with my homesickness in the continents of the world

I sleep on the surfaces of the trucks,

Tearfully looking at my distant homeland

Like a bird that does not know on which branch to perch. (Ibid, pp.103-104)

Without looking through the window of the train that passes through the steppes of his homeland, the poet knows exactly the rivers, prison cells, date palms and villages he is going to see. He keeps them by heart as he says. However, as he tells his mother:

He will not knock the door.

They are there behind the walls lying in wait for me

With their glossy blades.

Oh! My mother, Do not wait my letters

They are searching, among the dots and comma, for any word or a stir of life

So, sit in front of the window,

And listen to the wind of the night

Then, you will hear the confidential talk of my soul. (p.104)

Desperate of ever having the ability to return, and realizing the gruesome and terrifying living conditions in his homeland which deprive him of his basic human rights, Al-Sayegh can do nothing except going on in his "travels, giggles, and insults". He is a passerby

who has nothing except sidewalks and long cough,

Nothing except ink, stairs, and rain.

Walking like a lonely soldier,

Who drags, among the debris, the remains of his wounded life.

I want nothing. I want neither medals, insignia, drums, nor newspapers.

What I want is only to put my blistering forehead

On the mud of my homeland's rivers,

And die dreaming like the trees. (pp.106-7)

Like other exiles, the last wish of Al-Sayegh is to die and be buried in his homeland. He is still alive and is still writing about his homeland. Whether this wish will come true or not, no one is sure. 


\section{Conclusion}

As the analysis of what might be termed Al-Sayegh's 'exile poems' makes clear, the exile occupies a central place in both his prose and poetic works. In insistently writing about exile, Al-Sayegh wants to draw the attention to the dangers of estranging people and compelling them to think of alternatives other than living in their own homelands. Although different in nature, the poet has suffered both types of exile, internal and external. In exile, Al-Sayegh was in front of two choices: either to make use of the new climate of freedom and liberty he has or to imprison himself in the prison of the past painful memories. In his exile poems, Al-Sayegh purposefully does both things. He praises and relishes in the new opportunities offered to him in exiles like freedom of speech, discovery of new modes of thinking and writing while simultaneously harking back to his homeland, family, friends, and familiar places. The suggestive employment of juxtaposition, contrast, comparison, and irony are intended to show the differences between the ordeals which his homeland is passing through and the tendency to celebrate and cherish life in his exiles. This makes Al-Sayegh's 'exile poems' an indictment of all sorts of oppression, tyranny, and violence. They are the poet's main means of protesting and decrying the atrocities which his country had been going through during the last four decades.

\section{References}

Adelman, H. (2008). The refugee and the IDP problem in Iraq. In H. Adelman (Ed), Protracted displacement in Asia: No place to call home(181-209). Hampshire: Ashgate Publishing Limited.

Adnan, A. (2004). Complete poetical works. Beirut: The Arabic Institution of Studies and Publication.

Adnan, A. (2011). And. Beirut. Al-Kwakab Press Services.

Anderson, L. \& G. Stansfield. (2004). The future of Iraq: Dictatorship, democracy, or division? London: Palgrave Macmillan.

Al-Athari, L. (2008). This rhythm does not please me: Women protest war in Dunya Mikhail's poetry. Kansas: Kansas State University.

Al-Ubaidi, W. (2002). “An Interview with Adnan Al-Sayegh). Al-Thifaf Magazine. Issue no. 9. Retrieved October, 10,2015. URL (www.adnanalsayegh.com/ara/index.asp?DO...id=5)

Al-Zareebi, W. (2008). Adnan Al-Sayegh: The poet who carried his exile under his armpit." Tunisia: the Tunisian Company of publication and Plastic Arts development. Retrieved December, 8, 2015. URL(www.adnanalsayegh.com/TaabatTunisiaBook.pdf)

Arendt, H. (1951). On the nature of totalitarianism: An essay in understanding. Retrieved December, 8, 2015. URL (www.cas.umt.edu/.../152ArendtOnTheNatureofTotalitarianismAnEssayin...)

Buzarna-Tihenea, A.(---). "Representation of exile in Ian Mcewan's fiction.” Retrieved October, 12, 2015. URL (webbut.unitbv.ro/BU2014/Series\%20IV/.../10_SIB.pdf), 83-90.

Camelia, A. (---). Exilic Dimension of Modernism: D.H. Lawrence's 'Island'-Characters. Retrieved December, 5, 2015. URL (www.docin.com/p-424955657.html), 75-82.

Dobrinescu, A. M. (---). Travelling across cultures- Jhumpa Lahiri's interpreter of maladies. Retrieved October, 1, 2015. URL (shodhganga.inflibnet.ac.in/bitstream/10603/10930/8/08_chapter3.pdf), 101-108.

Dodge, T. (2003). Inventing Iraq: The failure of nation building and a history denied. New York: Colombia U.P.

Friedrich, C. J.(1953). The unique character of totalitarian society. In C. J. Friedrich (Ed.), Totalitarianism (47-60). Cambridge: Cambridge U.P.

Hanks, P.(Ed).(1974). Encyclopedia World Dictionary. Beirut: Color Press.

Iamandi, P. On Solaris: Exile the SF way. Retrieved December, 4,2015. URL(https://about.me/petru.iamandi), $173-179$.

Johnson, A. (December16,2005). Putting Cruelty First: An Interview with Kanan Makiya. Retrieved December, 5, 2015. URL(mercury.ethz.ch/serviceengine/.../Ch3_Putting_Cruelty_First.pdf)

Kurdi, M. (2010). A Woman Leaving Twice to Arrive: The Journey as Quest for a Gendered Diasporic Identity in Anne Devlin's After Easter. Estudios Irlandeses, 5, 58-67.

Mitrea, I. Re (creating) home from afar: memories of exile. Retrieved December, 4, 2015. URL(www.ceeol.com/content-files/document-52743.pdf), 127-133.

Nalepka, E. (2014). Saddam is Iraq and Iraq is Saddam: Saddam Hussain's Cult of Personality and the Perception of his Life and Legacy. Retrieved January, 10, 2016.

URL(www.academia.edu/.../Saddam_is_Iraq_Iraq_is_Saddam_Saddam_Huss...)

Rodrigues, A. L. (2007). The trauma of diminished Existence: Chinua Achebe Revisited. Postcolonial Text, 3(4), 1-23.

Rohde, A. (2010). State- Society relations in Ba'thist Iraq: facing dictatorships. London: Routledge.

Ropero, L. L. (2003). Diaspora: Concept, Context, and its Application in the Study of New Literatures. Revista Alicantina de Es tudios Ingleses. Retrieved November, 3, 2014.

URL(publicaciones.ua.es/filespubli/pdf/02144808RD16876886.pd):1-30. 
Said, E. (1994). Culture and imperialism. London: Vintage Books.

Said. E. (1996). Representation of the intellectual: The 1993 Reith lectures. New York: Vintage Books, 1996.

Said, E. (2000). Reflection on exile. In Reflections on exile and other essays. Cambridge, Massachusetts: Harvard University Press.

Said, E. (1990). "Reflections of exile." In R. Ferguson (Ed.), Out there: Marginalization and contemporary cultures(357-366). Cambridge: MIT Press.

Sassoon, J. (2011). Saddam Hussein's Ba'th Party: Inside an authoritarian regime. Cambridge: Cambridge University Press.

Tabori, P. (1972). The anatomy of exile: A semantic and historical study. London: George G. Harrap \& Co.

Tsaaior, J. T. (2011). Exile, exilic consciousness and the poetic imagination in Tanure Ojaide's poetry. Tydskrif Vir Letterkunde, 48 (1) 98-109. 